\title{
Report on the International Conference on Abraham Abulafia and the Early Maimonideans: Trends, Approaches, and Sceptical Strategies (March 12-15, 2018)
}

The purpose of the conference organised by Racheli Haliva was to celebrate and discuss Moshe Idel's new book, Abraham Abulafia's Esotericism: On Secrets and Doubts. The book will be published by De Gruyter (Berlin) during 2018-19 in the MCAS's publication series Studies and Texts in Scepticism (STIS).

The conference focussed on the different trends and sceptical attitudes Maimonideanism took in the thirteenth and fourteenth centuries by examining various approaches to major religious topics such as the nature of the Torah, the commandments, the Hebrew language, the people of Israel, and the land of Israel. This comparative approach points to distinctive philosophical trends-as represented by Samuel ibn Tibbon, Shem-Tov ibn Falaquera, Joseph ibn Kaspi, Levi ben Abraham, Isaac Albalag, Moshe Narboni, Zerahyyah Hen, and Hillel of Verona-focussing on major Jewish religious topics. Among these trends, the place of Abraham Abulafia and the early writings of Joseph Gikatilla, both of whom wrote commentaries on Maimonides' Guide of the Perplexed, stands out. The questions asked here concern the possibility of drawing a map of radical versus conservative Maimonideanism and to discern whether or not the two kabbalists are as radical as the philosophers in treating the same subject matter.

The conference was comprised of Kabbalah and Jewish philosophy scholars, including internationally renowned and established experts alongside new voices of a younger generation. All of the participants had received advance copies of Idel's book and had explored its various themes and intersections with their own respective research focusses. The conference combined formal lectures with a workshop format, and a considerable amount of time was allocated to free discussion. The report here will provide a chronological talk-by-talk overview and conclude with a short summary of a number of recurring themes that came up during the discussions, which can perhaps provide occasion for subsequent scholarship.

The conference opened with David Abulafia (University of Cambridge/UK), whose presentation "Naples and Mediterranean Crossroads" outlined the complicated history of the kingdoms of Sicily and Naples, mainly in the thirteenth century, and provided historical context for the intellectual undertakings explored in the conference. The presentation focussed on the reigns of Frederic II and his successor Charles I of Anjou, their politics and attitude to scholarship and non-Christian groups, and the condition of the Jewish community under both monarchs' rules. By the time Abraham Abulafia arrived at Capua in 1279, Charles had already stabilised his regime 
and had made attempts to convert the Jews, who until that period had been an integral part of society, enjoying the court's protection. A short time afterwards, a period of political and military turmoil begun, persisting for over 200 years, bringing with it rich apocalyptic literature.

Moshe Idel (Hebrew University of Jerusalem/Israel) outlined the conceptual framework of the subsequent presentations, describing "Abulafia's Commentaries on the Guide of the Perplexed" in terms of structure, circumstances of composition, reception, and influence. Abulafia wrote three commentaries on Maimonides' Guide of the Perplexed within a span of nine years (significantly more than any other scholar): Sefer Ge'ulah ('Book of Redemption,' 1273; probably written in Spain), Hayyei haNefesh ('Life of the Soul,' 1278/9; written in Byzantium), and Sitrei Torah ('Secrets of the Torah,' 1280; written in Capua). Of these, Sitrei Torah was the most read and the most influential. In fact, it survives in more manuscripts than all other thirteenthcentury commentaries on the Guide-by any author-and was also translated into Latin.

According to Idel, Abulafia was a passionate teacher of the Guide, which he taught in Barcelona, Castile, Byzantium, Capua, and Sicily. The three different commentaries arise from the fact that Abulafia's writings at the time addressed different audiences in different places. Idel claimed that Abulafia's teachings about the Guide and his exposing its secrets would have been one of the reasons he was forced to move from place to place. The commentaries were written for specific students, to whom Abulafia assigned numbers, complaining they were bad or poor students. His complaint was founded on his observation that whenever he progressed to a more advanced stage in understanding the Guide those students abandoned him.

Idel noted that when exploring Abulafia's works on the Guide it is important to keep in mind that he wrote them as a kabbalist rather than a philosopher. Indeed, Idel argued that, to a certain degree, Abulafia took the Guide to be the source of his Kabbalah. In so doing, he attempted to uncover the secrets of the Guide, which he deemed contained a kabbalistic nature. Abulafia, for instance, is one of the few commentators who implemented gematria when reading the Guide, facilitating it in an ecstatic context. Moreover, the work is understood not only as a guide to knowing secrets, but also as a guide to an experience: this particular experience being a Maimonidean prophetic experience.

In discussing the lasting influence of Abulafia's commentaries, Idel tentatively suggested considering the possibility that later commentaries on the Guide were written as a form of reaction to Abulafia. Whether or not this is the case, the wide distribution of manuscripts, especially of Sitrei Torah, is an extremely significant indicator of the dissemination and impact of Abulafia's commentary. Idel presented a long list of authors (Jewish as well as Christian) who have directly quoted or alluded to Abulafia's commentaries with or without proper attribution.

Idel argued that Abulafia's Kabbalah is intertwined with Maimonidean influence, which Abulafia never marginalised, even long after writing the commentaries. This influence is also felt in the negative reaction with which other kabbalists received 
Abulafia's commentaries after Abulafia was compelled to leave Spain. Abulafia's influence is tied in with his unique blend of Kabbalah and philosophy. His Kabbalah is idiosyncratic, but not to any extremes that would prevent his work from attracting audiences in significant circles. This form of 'Maimonidean Kabbalah' has interesting connections to Abulafia's fierce critique of rabbinic Jewry, his conception of Judaism as a universal entity, and his opening of the Jewish experience to non-Jews.

Idel ended his talk by musing about the transformation in the reception of Abulafia in Jewish orthodox literature; from being completely outcast to appearing frequently on the shelves of the bookshops of Jerusalem's ultra-orthodox neighbourhood Me'ah She'arim.

Gitit Holtzman (Levinsky College, Tel Aviv/Israel) discussed "Esoteric Philosophy, Prophecy, and Mysticism: R. Moshe Narboni's commentary on the Guide of the Perplexed as Revealed in the Commentary on al-Ghazali's Intentions of the Philosophers." Holtzman argues that Moshe Narboni's distinction between the exoteric and esoteric levels in Maimonides' Guide is reflected by his distribution of information among his different commentaries on philosophical works. Most importantly, she stressed Narboni's refusal to reveal the secrets of the Guide in his commentary on the work, referring his reader to his commentaries on al-Ghazali's Intentions of the Philosophers, Averroes' Letter about the Possibility of Conjunction with the Agent Intellect, and Ibn Tufail's Hayy ibn Yaqzān. In other words, to understand Narboni's views about the esoteric level of the Guide, one should study texts other than Narboni's commentary on the Guide.

Holtzman demonstrated this by analysing key passages of Narboni's commentary on Al-Ghazali's Intentions of the Philosophers, exploring the possibility that Narboni used what he took to be Maimonides' esoteric doctrine to explain al-Ghazali's text. Here Narboni claims, for instance, that al-Ghazali lived in an era in which the teaching of philosophy was forbidden and his apparent 'rejection' of philosophy is merely a ploy to communicate philosophical knowledge. In this context, Narboni borrows an idea he finds in Maimonides on the sages' necessity to disperse the knowledge that emanates from them. Another esoteric element is introduced regarding al-Ghazali's classifying fields of knowledge and their susceptibility to error, to which metaphysics is most prone. By way of explanation, Narboni indicates Maimonides' identical sentiment in the Guide. Other examples are given in the context of the need to accommodate positions to a different time and place. In conclusion, Narboni appears to think that Maimonides based all of the secrets of the Guide on the imaginative faculty.

The final example dealt with Idel's contention that, in a certain passage, Narboni is quoting Abulafia. Holtzman provided an alternative explanation, claiming them both to be drawing on Maimonides. Here she suggested Narboni is subtly criticising Maimonides for placing too much emphasis on the imaginative faculty.

In his presentation "Some Thoughts Regarding the 1270-1290 'Windows of Opportunities': Abulafia, Zerahyah, and Hillel on the Guide of the Perplexed," Yossi Schwartz (Tel Aviv University/Israel) proposed widening the intellectual and geo- 
graphical scope of Idel's notion of the 20-year 'window of opportunities'-a period of exceptional fertility in kabbalistic literature. The 'window of opportunities,' Schwartz argued, is wider than Castile and encompasses not only Kabbalah but Maimonideanism as well. Schwartz's presentation here pointed out the complex relation between Abulafia, Zerahyah ben Sha'alti'el Hen, and Hillel of Verona, the latter two having been active in Italy during the relevant time frame, a period in which Abulafia also spent much time there.

Aside from offering revisions to some accepted views on the chronology of events concerning Hillel and Abulafia, Schwartz argues that Abulafia, Hillel, and Zerahyah not only present three versions of Maimonideanism, but also three versions of Jewish Averroism. Unlike Abulafia, Hillel and Zerahyah were late bloomers and were only acknowledged for their work at a much later stage. There are interesting parallels in Zerahyah and Hillel's projects regarding the texts they translated (or for which they commissioned translations) that seem to indicate they were engaged in some sort of competition. This might have been a reflection of a professional dispute between physicians.

Aryeh Krawczyk (Jewish Historical Institute, Warsaw/Poland) discussed the notion of "Inner Speech (Endophasia) in the Thought of Maimonides and Abulafia." Introducing a multidisciplinary approach, Krawczyk employed neuro-cognitive theories of endophasia to shed interesting light on Maimonides' and Abulafia's respective approaches to the possibility of conjunction with the agent intellect. Krawczyk argued that inner speech plays an important role for both to achieve this effect.

After acknowledging the methodological challenges associated with research of this nature and the necessary caution it requires, Krawczyk addressed the distinction between ordinary and acute cases of endophasia. In neuropsychology, ordinary endophasia indicates a normal phenomenon such as talking to oneself, whereas acute cases indicate instances of hallucinations whereby the individual experiences voices speaking to them from outside. Krawczyk suggested that although one can find ordinary endophasia in Maimonides regarding the intellect and noetics by reference to sound and hearing in different chapters of the Guide of the Perplexed, Abulafia's writings contain several techniques and rituals that seem to be aiming at prompting acute cases of endophasia and heautoscopy (vision of oneself from the outside). To this end, Krawczyk analysed several examples from Abulafia's works like Sefer ha-Hesheq ('The Book of Desire') and Sefer ha-Ot ('Book of the Letter').

Steven Harvey (Bar-Ilan University, Ramat Gan/Israel) discussed "The Law of Moses in Maimonides, Abulafia, and Maimonideans." Prior to addressing the main issue, Harvey expressed reservation concerning the scholarly tendency of shifting away from the idea of esotericism in the medieval period. He argued that the denial of the historical phenomenon of the persecution of philosophers is factually incorrect and provided several counterexamples from the Islamic world. These examples are better suited to Plato's open reference to the danger of philosophy, as its opinions are in such contradistinction to those of the multitude, that philosophers are compel- 
led to conceal them. Plato's position set the tone for much subsequent philosophical literature that took heed of his warning.

Having reinforced esotericism within the philosophical tradition, Harvey suggested treating Abulafia as a missing link in the history of Maimonideanism and set out to express this through his silent absorption of Maimonides' conception of divine law in the Guide. The immediate context is Maimonides' distinction between divine and conventional law, of which only the former interests Maimonides. The criterion for the divinity of a law is its reference to the welfare of the body and to belief. Only with the existence of the two can a law be divine. Another criterion is that the lawgiver should be a prophet and denounce bodily pleasures. By putting forth these criteria, Maimonides followed in the footsteps of al-Farabi, as did Falaquera and Isaac Albalag, who nevertheless appropriate al-Farabi's views to neutralise his subordination of religious practice to philosophical truth.

An implicit difficulty in Maimonides' view is that it is hard to see how his understanding of divine law (according to the aforementioned criteria) harmonises with the idea of the singularity of Mosaic Law. Harvey showed that Averroes (who also follows al-Farabi's notion of divine law) is open to the possibility of a better religion emerging, which would also better represent the philosophical ideal. This, in fact, is what we find in Abulafia. Abulafia never addresses Maimonides' conception of the uniqueness of Mosaic Law but talks explicitly about a new Torah. According to Harvey, Abulafia thinks that Mosaic Law can be superseded, for a new prophet (he himself) has arrived.

Daniel Davies and Racheli Haliva (Universität Hamburg/Germany) explored the idea of "Tablets of Stone-Between Maimonides and Abulafia." The basic problem with which Davies and Haliva grappled was the ontological status of the tablets of stone. Although Maimonides insists that the tablets are 'natural' rather than 'artificial', it is unclear whether this means that 'natural' contains the 'miraculous' or denies both the 'artificial' and the 'miraculous'. Maimonides compares this issue to the notion of 'divine speech', which complicates matters further, as it is difficult to understand how the distinction between nature, miracle, and artifice applies to God's speech and will, or more broadly, to the issue of causality as applied to God.

In Abulafia this problem is translated into a multi-levelled understanding of the tablets and their significance. In Sefer ha-Melammed ('Book of the Teacher') Abulafia distinguishes-within the context of Mount Sinai-between tablets, letters, and writing in the general sense. In Or ha-Śekhel ('The Light of the Intellect') three levels of understanding are identified: either exoteric, or esoteric, or both (in which the exoteric is false). In reference to what is written on the tablets, in Shomer Miswah ('Keeper of the Commandment') Abulafia tells us that the tablets have two sides-front and back-corresponding to God's front (face) and back (actions).

Regarding speech and writing Abulafia distinguishes three kinds of sounds, which emerge from different parts of the mouth, and three kinds of speech, corresponding to physical writing, the spoken word, and the mental conception. It appears that Abulafia distinguishes divine speech from human speech on the basis 
that divine speech is creative. The presenters asked whether Abulafia's elaborations and distinctions could be understood as an interpretation of Maimonides' account of the tablets and the writing.

Adam Afterman (Tel Aviv University/Israel) discussed "Kabbalistic Reading of Maimonides' Concept of Revelation.” In his presentation, Afterman talked about mystical and noetic union in the Kabbalah and the Aristotelian tradition, with reference to the Neo-Aristotelian background of the Kabbalah, eschatological union in Maimonides, Abulafia, and other kabbalists. Afterman showed how Maimonides was used by various kabbalists to present different versions of eschatological union.

The Aristotelian background of Abulafia and other kabbalists in the thirteenth century is relevant, particularly concerning the possibility of conjunction with the agent intellect, and even the First Cause. The basic formula is the equation between knowledge and union, a point that has become increasingly important for several kabbalists who sought an ontological bridge between man and god. In this tradition, there is an important Neoplatonic presence, which adds the notion of communion to the notion of union, as the former involves the receipt of emanation (shefa) from the agent intellect through the imaginative faculty. Maimonides links this to prophecy. The idea of a union with God, with no mediation from imagination or emanation, is a more radical one.

Within this framework, Afterman argued that Maimonides is relatively moderate. He does not permit a union with the active intellect unless it is at the instant of death or after death. It is appropriate to medieval metaphysics to be free of the body to arrive at the realm of unity. This is the union of intellect-intellection-intelligible, liberation from plurality and individuality into something simple, unified, and eternal.

Abulafia, in turn, uses this metaphysics to explain acute and immediate transformation from man to angel, or son of God. He proposes many techniques, sometimes alongside the agent intellect. Abulafia deviates from Maimonides and permits this in this life. However, Afterman claimed that Abulafia sides with Maimonides by stating that this is rare and difficult to arrive at. Nevertheless, this is a radical reading of Maimonides, and it is enabled by Abulafia's contemporary philosophical climate.

After Abulafia, other, different forms of Kabbalah emerge. Nahmanides, for example, describes a process of purification of the body, the soul, and the intellect. In other words, a gradual integration into the Godhead. This differs from Abulafia, whose model is either/or. But for this different picture, Nahmanides also uses Maimonides. Nahmanides refers to Maimonides' discussion of posthumous unification when describing his own idea of an eschatological level in which man achieves unity with the Godhead at the end of the integration process. But Nahmanides takes this to the next level, stating that there are rare individuals who can fully integrate with the Godhead while still embodied, with no need to go through all of the steps. This recurs in various kabbalists, e. g., Isaac of Acre, in his book Oșar Hayyim ('Treasure of Life'). When one reaches this stage, it is presented as being in accordance with the Maimonidean eschatological union. 
Fabrizio Lelli (Università del Salento, Lecce/Italy) talked about "Translations and Commentaries of Abulafia," particularly into Latin during the fifteenth century. Starting from the discussion of humanist interests in Kabbalah, Lelli retraced Pico della Mirandola's connections with Jewish scholars by reference to Pico's search for Hebrew sources that can fit into his Christian fields of interest. He believes that Pico's views on universalisation and the idea of unity with the agent intellect may be based, in part, upon Abulafia via some kind of mediation.

Some of Abulafia's works were translated (or perhaps appropriated) into Latin at Pico's request by Mithridates, a Sicilian convert from Judaism. In Sicily there was a continuous tradition of Kabbalah stemming from Abulafia's students. It is possible that Mithridates' father-with whom Mithridates studied before his conversionwas part of this tradition. Mithridates' translations featured many adaptations that enabled an understanding of Abulafia in a Christian manner. Mithridates also adds several notes to prove that Maimonides was a kabbalist, which had a major impact on Pico. Lelli suggested the possibility that subsequent Jewish interest in Abulafia is an effect of the Christian interest in him and perhaps even an attempt to correct Mithridates and recheck Abulafia.

Haim Kreisel's (Ben-Gurion University of the Negev, Beer-Sheva/Israel) “Maimonides and Abulafia on Prophecy" was premised on the assumption that Maimonides would not recognise himself as the person whose positions Abulafia presents. According to Kreisel, it is strange to think of Abulafia's commentaries on the Guide as actual commentaries, as they are so different from what Maimonides writes. Although the order of 'secrets' in Abulafia's commentaries is in accordance with the Guide, their discussion has little or nothing to do with the Guide itself. Instead, there is some kind of link to the content of the secrets with occasional reference to Maimonides' text, which Kreisel labelled 'impressionistic'. In this respect Kreisel shared the frustration of Abulafia's students, who were also unlikely to see the connection between Abulafia's commentary and Maimonides' text. Kreisel suggested viewing Abulafia as drawing inspiration from Maimonides but focussing on the secrets themselves, particularly in letter combinations. Nevertheless, some influence is apparent, for instance, in the theory of prophecy.

Kreisel characterised Maimonides' theory of prophecy as understanding prophecy as a 'natural' phenomenon; there are certain preliminary conditions and preparations, which when met, render prophecy inevitable or nearly inevitable. This appears to be a radical departure from rabbinic literature and may have inspired Abulafia's view on preparing oneself for prophecy. Accordingly, the definition of prophecy is not the reception of a specific divine message or a specific revelation, but emanation-the question about the actual content of prophecy remains open. Kreisel noticed a slight shift between Maimonides' legal writings, in which prophecy is described as an intellectual phenomenon, and the Guide, in which the imaginative aspect is emphasised and there is no reference (in that context) to the Aristotelian vocabulary of the acquired intellect and the idea of conjunction. Instead, the intellect becomes acquired in the perfection of the intellect and the culmination occurs when 
prophecy is over, as prophecy is concerned with the body. Prophecy, as a message, is completely natural as an extension of the overflow. According to Kreisel, Abulafia seems to have adopted a Maimonidean model-at least its theoretical frameworkwhich Abulafia modified according to his needs.

Elke Morlok (Goethe-Universität Frankfurt am Main/Germany) discussed "Gikatilla on Language and the Status of the Text-On the Transition between Abulafian Concepts and the Theosophic-Theurgic Matrix.” Morlok focussed on the difference of approach between the kabbalist Joseph Gikatilla, who was Abulafia's student, and Abulafia himself. According to Morlok, after Gikatilla left Abulafia he turned to theosophic/theurgic Kabbalah, which is incompatible with Abulafia's noetic-linguistic approach. Gikatilla wrote Ginnat Egoz ('Garden of the Nut'), one of his most important early works, at the age of 26, while he was still Abulafia's student. After being exposed to new currents, he moved from an Aristotelian-Pythagorean approach to the Neoplatonic camp. Gikatilla also moved from Abulafia's idea of universalisation and interiorisation to a more traditional-liturgical and less abstract narrative focussing on the priority of the Jewish tradition. Hence, according to this sociological and epistemic criterion, only Jews, who keep the Halakha, can access truth on the basis of a complex mystical exegesis, into which one has to be initiated by a kabbalistic teacher. This differs from Abulafia's approach, which also propagates initiation into highly manipulative linguistic techniques, but simultaneously tends to expand the Kabbalah to encompass a universal application.

In the early works of Gikatilla, the fact that the Tetragrammaton is comprised of those consonants which can usually serve as vowels prescribes a special place for Hebrew vocalisation symbols (niqqud). For Gikatilla, the mystic operates within the sphere of the vowels, and becomes the middle point for the relation between the divine and human spheres. He arrives at the centre of the cosmos through language.

Morlok also referred to Gikatilla's notes on Maimonides' Guide in his Haśśagot ('Critiques'), an early work Gikatilla wrote while still very much under the influence of Abulafia. In the Haśśagot, Gikatilla interprets the 'Account of the Chariot' ( $m a$ ' $a$ seh merkavah) as the secret of the causal chain of everything and their existence from one another, from the first emanation to the middle of earth (which is not found in Abulafia). The idea of order has a performative aspect of language and ontology-the human organ becomes the seat for the divine. In this respect, the ritualistic aspect is emphasised, as there is correspondence between the human and divine being, which is also dependent upon the ethics of human behavior, explaining the centrality of the commandments, as exemplified later in his Sha'arei Orah ('Gates of Light').

Ofer Elior's (Ben-Gurion University of the Negev, Beer-Sheva/Israel and Hebrew University of Jerusalem/Israel) presentation focussed on "The Account of the Chariot in Maimonides, Abulafia, and Provençal Thinkers.” Elior discussed various interpretations of the 'Account of the Chariot' as a mirror through which he would then explore the thinkers' approach to scientific enquiry, particularly at junctures where tension arises between science and religion. The presentation did not focus on the entire 
account, but only on Ezekiel 1:24-25 ('When they [i.e. the creatures] moved, I could hear the sound of their wings like the sound of mighty waters, like the sound of Shadday, a tumult like the din of an army. When they stood still, they would let their wings droop. From above the expanse over their heads came a sound. When they stood still, they would let their wings droop.').

In Maimonides' exploration of this passage in the Guide, he refers to the Pythagorean theory of celestial sound as an interpretation for the sounds that the animals make. He notes that Aristotle disagrees with the Pythagoreans, but his criticism is not of this theory but of the basis of their explanations: a cosmological picture in which the stars are self-moving and the spheres are fixed. Elior claimed the question here to be whether or not Maimonides agrees with Aristotle; if he does, this means that Maimonides admits that a prophet was wrong.

According to Elior, many scholars addressed this issue, but no one referred to Abulafia's take on the matter. Before turning to Abulafia, Elior discussed several Provençal thinkers and presented a wide array of engagements with this problem, ranging from ascribing to Maimonides a rejection of Aristotle, to acknowledging that Ezekiel had in fact erred but dissociating this from his prophecy. Moving to Abulafia, Elior found difficulty in understanding his position but believed that he basically accepted the interpretation according to which Ezekiel was in fact wrong. Elior indicated several points where Abulafia refers to the interpretation of the Cherubim. In Sitrei Torah, for example, there is a passage where Abulafia-gematria aside-seems to be directly drawing from Maimonides' interpretation. However, Abulafia does not seem to address the problem resulting from Maimonides' understanding. Elior wonders whether Abulafia thinks that the problem of tension between science and faith is marginal. Gikatilla, for instance, directly addressed the contradiction between Aristotle and Ezekiel, and stressed the importance of explaining the contradiction and its genesis.

Josef Stern (University of Chicago/USA) spoke about "The Role of Language in Maimonides and Abulafia's Thought.” Unlike many medieval philosophers and theologians, Maimonides denies the divinity of language and the literal attribution of speech to God. Instead, he follows al-Farabi in distinguishing between things, utterances (or 'outer speech'), and traces in the soul (or 'inner speech'). For Maimonides, the relationship between logic and the intellect is analogous to the relationship between grammar and language. The traces in the soul comprise a complete system of interrelated concepts-a language with structure and syntax-a composite entity. On the background of the distinction between internal and external speech, Maimonides severely criticises external speech, limiting its function to communicating concepts to another person (this is why the spheres only have inner speech). The mental representations are the primary language, which functions independently of external speech, although access is only attained through external speech.

For Maimonides, languages in the sense of external speech (and only in that sense) are conventional rather than natural. The conventionality is expressed by the accidental relationship between the word and the mental representation it re- 
flects; conversely, the relationship between the mental representation and the external object is natural and universal (the same thought points to the same object). External speech is inferior to internal speech, just as the conventional is inferior to the natural. But despite this, Maimonides maintains that both inner and outer speech have syntax, composition, and structures. This is conditioned upon the imagination, the faculty of representation, which cannot perceive anything immaterial, hence it is still not good enough to represent immaterial simple beings; syntax is the matter that prevents the intellect from apprehending the subject matter of metaphysics, hence, from being perfected.

This is the point of friction with Abulafia, who sympathises with Maimonides' insight, but draws different conclusions. Abulafia takes the 22 consonants to be the matter (i.e., the 'linguistic potentiality') of the words. There is a natural process that creates, from this matter, the combinations of consonants whose vast number is capable of constructing any language. At the same time, there is an ontological process of emanation of things. The consonants in language are parallel to physical elements. For Abulafia, words are nothing but combinations of sounds, so that all languages are equal and generated in the same manner. What elevates Hebrew is that it offers the best phonetic articulation of the 22 consonants (the matter) - not that it is divine. As such, Hebrew becomes the representative of universal sound. The mission of the sage, then, is not to think the form of the words, but their matter-in precise opposition to Maimonides.

At the end of his talk, Stern addressed Maimonides' and Abulafia's parables of the pearl, even though (as Idel observes) we have no explicit evidence that Abulafia based his parable on Maimonides'. Stern, however, argued that there is indirect evidence in that the tri-partite structure of Abulafia's parables (as analysed by Idel) parallels the tri-partite semantic levels of the Maimonidean parable, a structure not found elsewhere. However, for Maimonides this semantic structure reflects the expressive function of a parable, not political esotericism, for which Idel argues, in the case of Abulafia. Further research will be necessary to delineate the exact contours of influence between the master and his disciple.

Hanna Kasher (Bar-Ilan University, Ramat Gan/Israel) discussed "Maimonides, Abulafia, and Joseph ibn Kaspi on The Hebrew Language." Maimonides and ibn Kaspi offer two opposing views on the status of Hebrew and the reason for its holiness, whereas Abulafia's view is difficult to discern.

Kasher showed that human language, for Maimonides, is conventional rather than natural. Accordingly, Hebrew is the holy language for circumstantial reasons, namely because it is part of a perfect climate area. According to this climatology, the pronunciation of its words is balanced, a feature of similar languages, such as Greek, Hebrew, Persian, and Aramaic. As regards the script, Maimonides seems to contrast it with Arabic, whose script is connected and contains many identical letters. There was probably a need to respond to the Arabs, who claimed Hebrew vocabulary to be lacking. Maimonides responds that the limited vocabulary in Hebrew 
is an advantage, as all of the inferior things (reproductive organs, for instance) do not have their own words, but are only alluded to. This is the mark of a divine language.

Kasher noted that neither ibn Kaspi nor Abulafia refer to Maimonides' attitude toward Hebrew. Ibn Kaspi addresses the issue of the Hebrew language in his Commentary on the Torah in which he advances that Arabic and Hebrew words are derived from reality, unlike Latin, whose words are random. Arguing with a Latin scholar on the Latin translation of the Bible, ibn Kaspi says that all of the Hebrew words have an informative meaning. The authors of this language understood this and made sure that each root has one meaning. Hence, the creators of language were philosophers, and Hebrew cannot be translated into other languages. Translation entails a 'unification of tongues,' whereas God wanted a 'division of tongues.'

Abulafia, who was active before ibn Kaspi, openly advocated the unification of languages, saying that there are many names to one being. Kasher wondered whether Kaspi's account can be taken as including a critique of Abulafia. She further noted Abulafia conceives language as natural and is also interested in bi-lingual education of children. The idea of a 'holy language' as that which is developed on a desert island-a commonplace idea since Herodotus-is for Abulafia nothing but a noble lie.

In his talk "Maimonides, Abulafia, and Spinoza," Zev Harvey (Hebrew University of Jerusalem/Israel) addressed three points of striking similarity between Abulafia and Spinoza, which, in his opinion, would be difficult to explain without recourse to some historical connections.

The first point is the identification of God and nature, well known from Spinoza's formula Deus sive Natura ('God or nature'). According to Harvey, Abulafia was the first to note that the gematria of God (elohim-(אלהים) and nature (ha-teva'-הטבע) is the same, namely 86. This identification is frequent in Abulafia's corpus, appearing ten times in his known works. This gematria was widely quoted in Jewish and Christian literature, some of which was familiar to Spinoza. The idea that God is nature suits Maimonides' thought as well. Abulafia returns frequently to this theme in the context of the tablets of the law. This is also frequent in other kabbalists and in Hebrew philosophical literature. According to Idel, Spinoza disentangled the linguistic/gematric mode and focussed on the content.

The second point takes on the issue of the intellectual love of God. According to Harvey, Abulafia was the first to coin the term ahavah elohit sikhlit, of which he maintained that amor Dei intellectualis is a good translation. The passage in which Abulafia coins the term is quoted in Narboni and in Abraham Shalom with no reference to Abulafia as its original author. The Maimonidean connection is established through the term or ha-śekhel ('the light of the intellect') which appears in the Guide.

The third and final point is the reestablishment of the Jewish state as a natural occurrence. In the Theologico-Political Treatise, Spinoza claims that laws are meant to be observed in a certain place and are irrelevant to other places. Hence, Jewish law belongs to the Jewish state, so it will become relevant again only if the Jews return to their homeland. Harvey noted that Shlomo Pines had detected the similarity between this idea and Joseph ibn Kaspi's contention that the possibility of the Jews returning 
to their homeland is not irrational. Spinoza explains that the return to the land of Israel is natural rather than miraculous. This idea, too, goes back to Abulafia.

In his Response, José María Sánchez de León Serrano (Universität Hamburg/Germany) focussed on the attempt to find precedents for Spinoza's identification between God and nature, arguing that thinking about sources for Spinoza changes the way we perceive him as an innovator. However, Sánchez de León attempted to stress the fundamental differences underlying the equivalence in formula. Alluding to studies that attempt to bridge the conceptual gap between Spinoza and his predecessors in this respect, Sánchez de León noted several areas in which the differences seem to outweigh the similarities; such as the availability of the concept of God to the human intellect, the philosophical status of language, and the radical transformation of the concept of nature.

Throughout the various discussions in the conference, a few recurring themes came up, which can perhaps prompt further scholarship on Abulafia within a Maimonidean context:

(1) The ambiguity of Abulafia's theoretical framework: Idel has shown that for Abulafia the use of contemporary philosophical jargon is instrumental rather than theoretical, namely to facilitate a certain experience in terms with which his audience could relate. Nevertheless, the question whether and how a coherent metaphysical backdrop can indeed be extracted from Abulafia-even if it has an ad hoc status-seems to warrant further study.

(2) In various cases it seems as if a key difference between Maimonides and Abulafia is that although Maimonides' Guide, in many cases, tries to address various philosophical topics (e.g. the structure of the cosmos, the phenomenon of prophecy, and the relation/tension between scripture and scientific truth), Abulafia is interested in facilitating change (e.g. elevating nature, becoming a prophet, altering the Bible). This distinction between static and dynamic undertakings raises interesting questions when exploring the manner in which Abulafia appropriates themes from Maimonides.

(3) The identification between God and nature in Abulafia and Maimonides can mean different things and can be employed (among other things) to assert transcendence as well as reinforce immanence. Furthermore, understood within the context of creativeness, the status of the artifice and the miraculous, derivatively, require additional clarification. The different options can be explored more fully, also concerning subsequent developments in the Kabbalah.

(4) The status of gematria has raised some questions, especially assuming that letters are the building blocks of the cosmos. The gematric equivalence of different expressions, Abulafia argues, is not accidental or random but seems to point to some logical connection between them. Hence, if gematria is not only a tool for mystical experience but also an expression of the architecture of the world, it should be explained within a metaphysical framework. Moreover, and perhaps significantly, within the context of language, the question of the relationship between 'The Holy Language' and Hebrew emerges at various junctures here. 